\title{
LGBTQ: The Molecular Mechanism and its Role in Elucidating Proportional for a Better Management
}

\author{
PeniKistijaniSamsuria Mutalib ${ }^{1}$, Belinda Y Murtani ${ }^{2}$, Muhammad Taufiq Dardjat ${ }^{3}$, \\ AnwarSoefi Ibrahim ${ }^{4}$, Meny Hartati ${ }^{5}$ \\ ${ }^{1,4}$ Medical Physics Department, Faculty of Medicine, Universitas Indonesia \\ ${ }^{1,3}$ Cluster of Medical Technology, Faculty of Medicine, Universitas Indonesia \\ ${ }^{2}$ International Class, Faculty of Medicine, Universitas Indonesia \\ ${ }^{5}$ Pathology Anatomy, Faculty of Medicine, Universitas Indonesia
}

\begin{abstract}
-
Background: LGBTQ is prone high prevalence and has economic, social business grow in wet and warm countries. It becomes political issue Worldwide (Time magazine, June 12, 2017, page 7) in immigration and also president election campaign in industrial countries in the last decades.

Problem: Current effort from day care psychosocial early predictive and training, better therapy, law in sentence, marriage and immigration/ refugee has become topic of controversies feel not ended. From psychiatry social, transgender operation and hormonal have been the day fact, but not one make it clear from the molecular aspect as the cause, and what to do in prevention, promotion for keeping away from methylation and demethylation affect. This study digs the reference about $C G G$ repeat in large to small DNMT off.

Objective: CGG repeat as the molecular aspect of methylation and demethylation beyond health science should build and known by decision and policy maker. Controversial are broad, LGBT problem are hug, increasing but attorney denies that gay people exist in their region (Times magazine, June 12, 2017, page 7).
\end{abstract}

Method: Systematic Review with Bayesian analysis and mathematical model.

Result: flowchart and table of 13 ref from CGG repeat in DNA methylation analysis, 2 Meta-analysis. Small grey zone CGG repeat associated with neuropsychiatric risk.

Discussion: Brain and behavior DNMT off functional.

Comparison: Law, neuropsychiatric/early social-education vs. ensure no to methylation and demethylation in wet and warm area.

Outcome: Winning the combat of LGBT prevalence.

Conclusion: Winning the combat of LGBT prevalence not with early psycho-social activity, but with molecular psycho forensic and that is through what cause small/ grey zone CGG repeat prevalence.

Keywords—psycho-social, psycho forensic, biophysics, grey zone. CGG repeat, brain and behavior of LGBT.

\section{INTRODUCTION}

Molecular aspect approach policy on LGBT high prevalence have never been bring in fighting/ combat it. Behavior problem large to Small CGG repeat LGBT law/psycho-social/MGMT has been reported due to DNMT off gene, DNA Methyl Transferase in brain functional. Street fashion carnival business, club, and cabaret vs. grey zone and premutation CGG repeat that off DNMT and make functional brain and behavior problem has become the channeling of many district governments. Health science intense the early detection in day cares and teaches and train psycho-social activities as prevention to LGBT behavior. Nowadays, Social category label (SCL) and future direction are topics in top executive government authoritarianism. ${ }^{1}$ Brain and behavior gene in mood disorders and in promoter gene in methylation has been reported. ${ }^{2}$ Psychological status of premutation showing a complex with the size of small CGG repeat (50-141) which associated with methylation on DNMT. ${ }^{3}$ Premutation (55-200 CGG repeat) on FMR1 gene and mRNA level reported higher level in obsessive-compulsive symptom and RNA toxic gain-of-function model in a neuropsychiatric phenotype. ${ }^{4}$ 


\subsection{Background}

At least, 2 professors from Top Farmer Institute in wet and warm country ask The Constitutional court that LGBT behavior without thinking of their ages, should be sentence maximum 5 years without asking the age, also for 10 years old boys and girls. ${ }^{5}$ While sex party with men striptease caught 149 'men' in wet and warm conservative countries on 21/5/2017 in Kelapa Gading, ${ }^{6}$ Orlando nightclub shooting on June 122016 with 49 dead are shocking peoples local and global, Jember Fashion Carnival as street Festival every years are think as a good cultural valve with given satisfied feeling to the district municipal government, while the parents are proud and doesn't know about the psychology label next. ${ }^{7}$ In world level, Putin and Macron dispute about Gay right in Chechnya. ${ }^{8}$-Time Magazine- June 12, 2017 p7-, the Chechnya authorities proclaimed, there is no LGBT cases in their country. Then The Telegraph writes that Angela Merkel urges Vladimir Putin to protect Chechnya gay rights. ${ }^{9}$

\subsection{Problem}

The issue about LGBTQ has been sharply increased in these days including in Indonesia. Vitriolic critics against LGBTQ keep ongoing as it is thought as morally unacceptable behavior by the community. People considered it as a social crime leading to discrimination in many aspects for the LGBTQ peoples. Government Concern in street fashion carnival, club, cabaret in many wet and warm countries and the state in one hand function as open the valve in the cultural best way, and the other hand neglected grey zone small CGG which off DNMT gene aspect, so that misleading the cause of LGBT and losing one's way the change to eradicate what caused of small CGG repeat in plant and human in tropical rainforest wet and warm climate condition. Meanwhile, predispose premutation to FXTAS (Fragile X Tremor Ataxia Syndrome) are associated in the CGG repeat. ${ }^{10}$

\subsection{Objective}

To socialized this molecular aspects etiology of LGBTQ as a part of LGBTQ management. Aware of micromolecule in LGBT mental: small amount of CGG repeat-LGBT should be done broadly beyond health department not only by executive, legislative, but also judicative decision maker and policy doer.

\section{METHOD}

Systematic review and Bayesian network analysis with mathematical model. Meta-analysis, cohort and DNA/ RNA analysis epidemiological are preferable than longitudinal, case control, distributional. EBSCO host, PubMed, DynaMed: Evidence Based; point-of-Care reference search engine are used for scanning title and abstract, then filtered by duplication and not relevant to CGG repeat large to small amount in association with brain and behavior functional. Key words of CGG repeat and psychiatric and psychological disorder are used in searching using Bayesian network analysis synonym. Mathematical model is used in determining quantitative and qualitative result of the reported references.

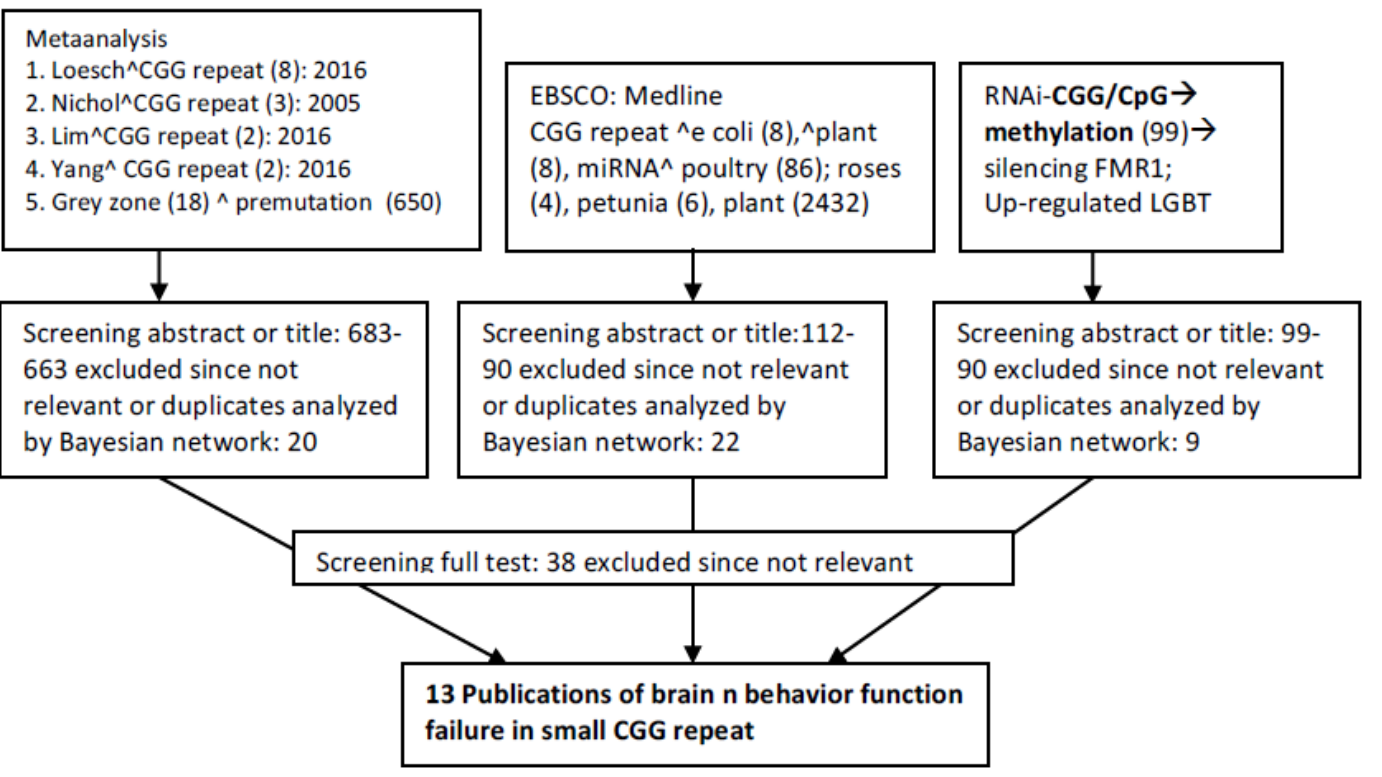

FIGURE: FLOWCHART OF THE 13 IDENTIFIED LITERATURES ON THE ASSOCIATION OF SMALL CGG REPEAT AND LGBTQ MENTAL 
Flowchart is build by PRISMA. Three groups of meta-analysis on authors and epidemiological writing are first scanned, then association between full, premutation and grey zone with psychological disorder, and thirdly small CGG repeat in grey zone and under and DNMT off, are used for searching in scanning all reference. Filtering the reference excluded and check and recheck with Bayesian network analysis and reference already known, some reference is printed out for the full text references. According to the objective to build association in CGG repeat and brain $\mathrm{n}$ behavior psychiatric function, also CGG repeat in stress and adaptation in plant, and about grey zone CGG repeat, all general knowledge is drop and specific references that support the objective are taken and write in the table.

\section{RESULT}

It is suggested that repeated CGG sequences plays a role in the pathogenesis mechanism of LGBTQ which is in parallel with CGG repeat expansion on Xq27.3 gene in Fragile X Syndrome manifested in both mental and physical disturbances. ${ }^{11}$ The existence molecular explanation of the underlying mechanism of LGBTQ is expected to be used appropriately as a direction to generate fair regulation to manage LGBTQ in the community, thus resulting into mutually beneficial outcome for all parties.

TABLE 1

THIRTEEN PUBLICATIONSABOUT SMALL CGG REPEAT TO BRAIN N BEHAVIOR FUNCTION FAILURE REPEAT

\begin{tabular}{|c|c|c|c|c|}
\hline Study, $\mathbf{y}$ & Design & Population & CGG repeat & $\begin{array}{l}\text { Methylation/ } \\
\text { Demethylation }\end{array}$ \\
\hline Hansen 1992 & $\begin{array}{l}\text { CT Methylation } \\
\text { Analysis }\end{array}$ & $\begin{array}{l}\text { CpG island of the human FMR1 } \\
\text { gene FRAXA and cariers }\end{array}$ & CGG sites & Hypomethylation analysis \\
\hline Nichol 2002 & CT DNA sequences & $\begin{array}{l}\text { CpG methylation bacterial and } \\
\text { primate cell system }\end{array}$ & Tandem repeat & Methylation stabilized \\
\hline Nichol 2005 & $\begin{array}{l}\text { CT DNA } \\
\text { methylation }\end{array}$ & Deletion hotspot region of FMR1 & CGG repeat & $\begin{array}{c}\text { DNA Hypermethylation } \\
\text { Silencing/off tumor } \\
\text { suppressor }\end{array}$ \\
\hline Nichol 2005 & $\mathrm{CT}$ & $\begin{array}{l}\text { Primate cell with SV40 primate } \\
\text { replication system }\end{array}$ & $\begin{array}{l}\text { Absence of } \\
\text { aberrant CpG } \\
\text { methylation }\end{array}$ & CGG Repeat deletion \\
\hline Hessl 2005 & $\begin{array}{l}\text { Recent documented } \\
\text { CGG repeat size }\end{array}$ & $\begin{array}{c}\text { Premutation alleles (55-200 CGG } \\
\text { repeat) of FMR } 1 \text { gene and } \\
\text { abnormal elevation of FMR1 } \\
\text { mRNA }\end{array}$ & $\begin{array}{l}\text { Gene-brain- } \\
\text { behavior } \\
\text { mechanism }\end{array}$ & $\begin{array}{l}\text { Tremor/ataxia, } \\
\text { psychiatric disorders in } \\
\text { children and adults }\end{array}$ \\
\hline Grigsby 2006 & Preliminary study & $\begin{array}{c}\text { 50-200 CGG repeat size } \\
\text { Executive cognitive Functioning } \\
\text { in FXTAS }\end{array}$ & $\begin{array}{l}\text { CGG repeat in } \\
\text { FMR1 gene }\end{array}$ & $\begin{array}{c}\text { Marked impairment of } \\
\text { executive cognitive } \\
\text { abilities. }\end{array}$ \\
\hline $\begin{array}{c}\text { Jacquemont } \\
2006 \\
\end{array}$ & $\begin{array}{l}\text { Meta-analysis } \\
\text { genetic screen }\end{array}$ & $\begin{array}{c}\text { Genetic screens CGG } \\
\text { premutation } \\
\end{array}$ & CGG repeat & Suggesting genetic testing \\
\hline $\begin{array}{c}\text { Naumann } \\
2014\end{array}$ & $\begin{array}{c}\text { Documented } \\
\text { Hypermethylation }\end{array}$ & 65-70 CpGs upstream FMR1 & $\begin{array}{l}\text { CGG repeat } \\
\text { premutation } \\
\text { carriers }\end{array}$ & $\begin{array}{l}\text { Promotor is inactivated } \\
\text { by methylation spreading }\end{array}$ \\
\hline Deng 2015 & $\begin{array}{l}975 \text { OF GENOME } \\
\text { IN HUMANS, IS } \\
\text { NONCODING } \\
\text { DNA }\end{array}$ & $\begin{array}{c}\text { miRNA-induced RNAi by } \\
\text { utilizing miRSC in } \\
\text { Caenorhabiditiselegans as native } \\
\text { RNA fragments }\end{array}$ & $\begin{array}{c}\text { Using } \\
\text { intronicmiRNA } \\
\text { (single-stranded } \\
\text { noncoding RNAs }\end{array}$ & $\begin{array}{l}\text { Gene silencing in vitro } \\
\text { and in vivo }\end{array}$ \\
\hline Yang 2016 & SR and MA & $\begin{array}{l}\text { 5-55 repeat numbers: <26 vs. } 26- \\
34 v s .35-54\end{array}$ & $\begin{array}{c}\text { CGG repeat } \\
\text { polymorphism }\end{array}$ & $\begin{array}{c}\text { Neuropsychiatric risk as a } \\
\text { routine test }\end{array}$ \\
\hline Loesch 2012 & Relation & $\begin{array}{c}\text { FXS, a severe } \\
\text { neurodevelopmental anomaly }\end{array}$ & $\begin{array}{l}\text { Grey zone, } \\
\text { premutation }\end{array}$ & $\begin{array}{c}\text { Neurodevelopmental, } \\
\text { cognitive, behavioral and } \\
\text { physical changes }\end{array}$ \\
\hline $\begin{array}{l}\text { Chandrasekara } \\
2015\end{array}$ & Screening & $\begin{array}{l}\text { DNA extracted from buccal cells: } \\
\text { CGG repeat of FMR1 gene in } \\
\text { special education children in Sri } \\
\text { Lanka }\end{array}$ & Grey zone & $\begin{array}{l}\text { Learning, emotional, } \\
\text { behavior problems }\end{array}$ \\
\hline Usdin 2014 & Review & $\begin{array}{c}\text { Human different cells Epigenetic } \\
\text { changes }\end{array}$ & $\begin{array}{l}\text { Number of CGG } \\
\text { repeat }\end{array}$ & $\begin{array}{c}\text { Ameliorating } \\
\text { Neurodegenerative } \\
\text { disorder }\end{array}$ \\
\hline
\end{tabular}


The correlation of CpG islands and CGG methylation with silencing of the FMR1 genes. ${ }^{12,13,14,15}$ Widely known 200-4000 CGG repeat in full mutation in FMR1 gene give Fragile X Syndrome. CGG repeat size 55-200 as premutation is associated with psychiatric disorder, ${ }^{4}$ impairment of cognitive abilities, ${ }^{16}$ and suggesting in genetic testing. ${ }^{17}$ In $65-70 \mathrm{CpG}$ upstream CGG repeat in FMR1 gene become stable DNA methylation boundaries and expanded CGG repeat. ${ }^{11}$ These promoter is inactivated by methylation spreading CGG repeat premutation carriers. Methylation boundaries exert an important function as promoter safeguards. Expansion and hyper-methylation of a CGG repeat tract are the main causes of fragile X syndrome (FRAXA).${ }^{14}$ Hypermethylationof CGG repeat are part of the CpG Island that is methylated. Small CGG expansions are unmethylated in the $\mathrm{CpG}$ island in normal males, unaffected fragile- $\mathrm{X}$ males. ${ }^{18}$ Learning, emotional and behavior could be found in buccal cell grey zone 5-25 CGG repeat number and suggested as routine test. ${ }^{19,}{ }^{20,}{ }^{21}$ These grey zone and premutation related with Neuro developmental, cognitive, behavioral and physical changes was reported. ${ }^{22}$ Epigenetic changes is also cover what is currently known about the mechanisms responsible for repeat instability that affect expression of the FMR1 gene should also ameliorating this molecular aspect of small CGG repeat. ${ }^{23}$

Thirteen references about CGG repeat in full, premutation, grey zone and below 55 and CGG repeat in human could be seen from the table 1.

\section{DISCUSSION}

\subsection{Introduction CGG repeat in full- premutation-grey zone in association with Brain and Behavior}

CGG repeat in association with methylation and demethylation, in DNMT gene affect brain and behavior function. Expansion and shorten CGG repeat to small amount CGG repeat has DNMT function failure, normally are 26-34. ${ }^{24}$

\subsection{CGG repeat problem in LGBT mental is in high prevalence in Wet and Warm countries}

LGBT are in High prevalence in Tropical Rainforest Area, South East Asia, Puerto Rico USA, Sweden Europa, Brazil, Thailand CGG. CGG repeat are higher in Thailand vs. Germany 2014, low prevalence parallel with Non GMO eater. Epidemiologies of LGBT are also high in other wet and a warm country such as Sierra Leone, West Africa, USA pop 25\% has LGBT Gallup.com: Puerto Rico and Orlando. LGBT and Transexual operation are high in Bangkok

In Indonesia: LGBT and fashion open air is also neglected: Jember Fashion Carnival 2017 are now as the icon of \#wonderful Indonesia. thejacartapost.com August 14, 2017: 12.06 pm; Transgender right in Brazil are high with Gender identity legal since 2009. An LGBT person is murdered every 28 hours in Brazil, with intake of Aflatoxin, p53-methylation are in high prevalence. Micro rainbow in Brazil is a project in development the talent of LGBT crisis.

\subsection{CGG repeat in plant in association with DNMT off in CGG repeat}

Gene silencing in vitro and in vivo using methylation for gene silencing and demethylation with miRNA etc. are broadly used for a long time in plant and animal. ${ }^{24,25,26,27,28,29}$ Expanding CGG repeat with hypermethylation from small CGG repeat (e.g. 5-54) become higher CGG repeat (56-4000) and hypomethylation from normal (26-34) degraded to < 26 (5-25 CGG repeat). ${ }^{21}$ Small CGG repeat should support LGBT law/psycho-social/MGMT has not previously been reported. Controversial are broad, LGBT problem are huge, increasing but attorney denies that gay people exist in their region (Times magazine, June 12, 2017, page 7)

Interference: Aware of molecular aspect in LGBT mental: amount of CGG repeat-LGBT will support. RNA that is an antisense repressor of the replication of some E coli, plasmid. FX Syndrome is caused by silencing of FMR1 gene, MartinBell-Renpenning Syndrome in Brazil are similar with Escalante's syndrome used in South American countries, but this practice is now being abandoned. Exposure of miRNA could methylated or demethylated and lengthen or smaller Repeat CGG. ${ }^{30}$ Methylation control reversible epigenetic mechanism ${ }^{31}$ in roses, poultry, e coli have the same mechanism as Methylation in FMR1

\subsection{They Need for help, not sentence and how could it be}

Religion Ministry of Indonesia announce that LGBT should be protected in a true way, but there is consistent not to support the LGBT, not that meaning to be support, to be discredited by religion, but should be hug so that the behavior and sexual orientation should be following what should be donecommensurate of what have teaching by the religions. Consistent not to straighten out these growing up population, LGBT, not to imply to isolate but should be embraced so that the behavior and 
sexual orientation as which said in the holly books. One large global franchise such as Starbuck pro LGBT, they said LGBT should be help LGBT needs help http://tv.detik.com/20detik/detailvideo/170703025/

Fighting LGBT which prone to pandemic has support pathogenesis mechanism in biophysics aspect: small CGG repeat in epigenetic in enzyme functional beyond health sciences (plant). Wet and warm GME in association with biophysics approach, supported by Bayesian analysis and mathematical model, has revealed this pathogenesis mechanism. Brain and behavior DNMT off functional, through passed up regulated DNMT in epigenetic toxicity in demethylation lower than 6 CGG repeat should be performed as toxic 'gene-of-function'.

Winning the combat of LGBT prevalence not with early psycho-social education, but with psycho forensic and that is through what cause small/ grey zone CGG repeat prevalence. These small molecule brain and behavior support could combat LGBT and HIV comorbidities where is nowadays rise to the surface that religion and culture Indonesia local wisdom to global in hugging the LGBTQ will undermine the Fight against HIV. Repeat CGG in small amount will combat the Mortality and Comorbidities and disabilities in brain, behavior and weaken memories (Mental Retarded). Repeat CGG, methylation CpG island in Brazil; outcome Dx\& Rx in LGBT pts.; in Bangkok were cause by the using of RNAi and CGG repeat in plant and animal. MiRNA induce RNAi (interference RNA) and demethylation/ hypomethylation is a new target therapy on the silencing complex (mRISC) to target miRNAs. ${ }^{29,32,33,34,35}$ The race of 10 synthetic RNAi Based drugs to the pharmaceutical market and attention of pharmaceutical industry rapidly turned to RNAi, as an opportunity to explore new drug targets. ${ }^{30}$ Off (methylation) the gene and on (demethylation) are the principle of transgenic MGO that these last decades succeed astonishing with Double KO, Turbo KO roses and many other plants ${ }^{24,36,37}$ and human ${ }^{38,39}$ Plant that resist from cold, hot, wet, dry condition and climate together with lasting and beautiful has been lured all of us without precise knowing what have done to it in these last 2 decades.

\section{LIMITATION}

Various limitation of this Systematic Review is recorded: 1) none published activity to defend food crisis, energy crisis and global warming to be the burden of tropical rainforest area. 2) Methylation and demethylationas an updated business should be control in sustainable global energy and move to sustainable 'hara' means NPK from plant specific rich in wet and warm countries. In local area specific without double and turbo, which the superior gene were made in rich sustainable 'hara' area. So, we build our one world proportionally to the demand and local needs, which means not tropical rainforest area wet and warm climate condition for all. Tropical rainforest sustainable 'hara' just for all specific condition, ensuring no'demethylation through pass' as the cause of LGBT high prevalence. We managed these problem by underline 'demethylation through pass' and methylation in prevention, therapy and socialization of LGBTQ.

\section{Conclusion}

The relationship between CGG sequences repeat and LGBTQ will replace discrimination and resulting into appropriate management of LGBTQ which will be elucidating proportionally.

\section{SUGGESTION}

Awareness to policy maker and decision doer in small CGG repeat.

Government Concern needs this molecular aspect from local Wet and Warm countries present to Global Health Problem.

\section{ACKNOWLEDGEMENT}

This study was supported by a research grant from the Universitas Indonesia 2015 with Grant No. 1772/UN2.R12/HKP.05.00/2015. CRID-TropHID in supporting the effect of high relative humidity on tropical health and infectious diseases modul especially on heat stroke, fungi sporulation and sepsis: SIAGNG XGA 10053. Compiling Tropical Health and Infectious disease module Competition from Faculty of Medicine UI 2010, by giving $1^{\text {st }}$ winner on e-learning. Also first winner in epidemiological poster on aflatoxin exposure on Dies natalis of FMUI. $1{ }^{\text {st }}$ ICGH (International Congress in Global Health) on 16 August 2017 who let us give poster presentation on no. 10261 in booth 9. We also thank DidikAryono, $\mathrm{MD}, \mathrm{PhD}$ for the supporting comment of psychiatric forensic in molecular aspect of LGBTQ.

\section{DisClOSURE}

Nothing to declare. 


\section{REFERENCES}

[1] Crawford JT, Brandt MJ, Inbar Y, Mallinas SR. Right-wing authoritarianism predicts prejudice equally toward "gay men and lesbians" and "homosexuals". J PersSocPsychol 2016;111(2):e31-45.

[2] Dell'Osso B, D'Addario C, Carlotta Palazzo M, Benatti B, Camuri G, Galimberti D, et al. Epigenetic modulation of BDNF gene: differences in DNA methylation between unipolar and bipolar patients. J Affect Disord 2014;166:330-3.

[3] Loesch DZ, Bui MQ, Hammersley E, Schneider A, Storey E, Stimpson P, et al. Psychological status in female carriers of premutation FMR1 allele showing a complex relationship with the size of CGG expansion. Clin Genet 2015;87(2):173-8.

[4] Hessl D, Tassone F, Loesch DZ, Berry-Kravis E, Leehey MA, Gane LW, et al. Abnormal elevation of FMR1 mRNA is associated with psychological symptoms in individuals with the fragile X premutation. Am J Med Genet Part B, Neuropsychiatr Genet Off PublIntSocPsychiatr Genet 2005 Nov 5;139B(1):115-21.

[5] Guru Besar IPB Dkk Minta LGBT Dipenjara 5 Tahun: KUHP Sudah Tidak Relevan [homepage on the internet]. c2016 [updated 2016 Jul 19 ; cited 2017 Aug 16]. Available from : http://news.detik.com/berita/3256327/guru-besar-ipb-dkk-minta-lgbt-dipenjara-5-tahun-kuhp-sudah-tidak-relevan

[6] 114 Arrested over Alleged 'Gay Party' in Kelapa Gading [homepage on the internet]. c2017 [updated 2017 May 22; cited 2017 Aug 6]. Available from : http://en.tempo.co/read/news/2017/05/22/057877512/114-arrested-over-alleged-gay-party-in-kelapa-gading.

[7] Susilo Wardhani MD. As stated in WA from Susilo Wardhani, MD August 4, 2017

[8] Rachael Revesz. Emmanuel Macron challenges Vladimir Putin on gay rights in Chechnya and Syria conflict[homepage on the internet]. c2017 [updated 2017 May 30; cited 2017 Aug 6]. Available from: http://www.independent.co.uk/news/world/emmanuel- macronvladimir-putin-gay-rights-chechnya-russia-france-syria-conflict-civil-war-assad-a7762591.html

[9] Chiara Palazzo. Angela Merkel urges Vladimir Putin to protect Chechnya gay rights. [homepage on the internet]. c2017 [updated 2017 May 3; cited 2017 Aug 6]. Available from : http://www.telegraph.co.uk/news/2017/05/03/angela-merkel-urges-vladimir-putin- protectchechnya-gay-rights/

[10] Chonchaiya W, Nguyen D V., Au J, Campos L, Berry-Kravis EM, Lohse K, et al. Clinical involvement in daughters of men with fragile X-associated tremor ataxia syndrome. Clin Genet. 2010;78(1):38-46.

[11] Naumann A, Kraus C, Hoogeveen A, Ramirez CM, Doerfler W. Stable DNA methylation boundaries and expanded trinucleotide repeats: role of DNA insertions. J MolBiol 2014;426(14):2554-66.

[12] Hansen RS, Gartler SM, Scott CR, Chen SH, Laird CD. Methylation analysis of CGG sites in the CpG island of the human FMR1 gene. Hum Mol Genet 1992;1(8):571-8.

[13] Nichol K, Pearson CE. CpG methylation modifies the genetic stability of cloned repeat sequences. Genome Res 2002;12(8):1246-56.

[14] Nichol Edamura K, Pearson CE. DNA methylation and replication: implications for the "deletion hotspot" region of FMR1. Hum Genet 2005;118(2):301-4.

[15] Nichol Edamura K, Leonard MR, Pearson CE. Role of replication and CpG methylation in fragile X syndrome CGG deletions in primate cells. Am J Hum Genet 2005;76(2):302-11.

[16] Grigsby J, Brega AG, Jacquemont S, Loesch DZ, Leehey MA, Goodrich GK, et al. Impairment in the cognitive functioning of men with fragile X-associated tremor/ataxia syndrome (FXTAS). J NeurolSci 2006;248(1-2):227-33.

[17] Jacquemont S, Leehey MA, Hagerman RJ, Beckett LA, Hagerman PJ. Size bias of fragile X premutation alleles in late-onset movement disorders. J Med Genet 2006;43(10):804-9.

[18] Hansen RS, Gartler SM, Scott CR, Chen SH, Laird CD. Methylation analysis of CGG sites in the CpG island of the human FMR1 gene. Hum Mol Genet 1992;1(8):571-8.

[19] Chandrasekara CHWMRB, Wijesundera WSS, Perera HN, Chong SS, Rajan-Babu I-S. Cascade Screening for Fragile X Syndrome/CGG Repeat Expansions in Children Attending Special Education in Sri Lanka. PLoS One 2015;10(12):e0145537e0145537.

[20] Yang W, Fan C, Chen L, Cui Z, Bai Y, Lan F. Pathological Effects of the FMR1 CGG-Repeat Polymorphism (5-55 Repeat Numbers): Systematic Review and Meta-Analysis. Tohoku J Exp Med 2016;239(1):57-66.

[21] Lim GXY, Loo YL, Mundhofir FEP, Cayami FK, Faradz SMH, Rajan-Babu I-S, et al. Validation of a Commercially Available Screening Tool for the Rapid Identification of CGG Trinucleotide Repeat Expansions in FMR1. J Mol Diagnostics JMD 2015;17(3):302-14.

[22] Loesch D, Hagerman R. Unstable mutations in the FMR1 gene and the phenotypes. AdvExp Med Biol 2012;769:78-114.

[23] Usdin K, Hayward BE, Kumari D, Lokanga RA, Sciascia N, Zhao X. Repeat-mediated genetic and epigenetic changes at the FMR1 locus in the Fragile X-related disorders Repeat-mediated genetic and epigenetic changes at the FMR1 locus in the Fragile X-related disorders. 2014;

[24] Xu M, Li X, Korban SS. DNA-methylation alterations and exchanges during in vitro cellular differentiation in rose (Rosa hybrida L.). TheorAppl Genet. 2004;109(5):899-910.

[25] Hardcastle TJ. High-throughput sequencing of cytosine methylation in plant DNA. Plant Methods 2013 Jan [cited 2015 Jul 1];9(1):16.

[26] Dubin MJ, Zhang P, Meng D, Remigereau M-S, Osborne EJ, Paolo Casale F, et al. DNA methylation in Arabidopsis has a genetic basis and shows evidence of local adaptation. Elife 2015;4:e05255-e05255.

[27] Kim SH, Kim SH, Palaniyandi SA, Yang SH, Suh J-W. Expression of potato S-adenosyl-L-methionine synthase (SbSAMS) gene altered developmental characteristics and stress responses in transgenic Arabidopsis plants. Plant PhysiolBiochem PPB 2015;87:8491. 
[28] Ma N, Chen W, Fan T, Tian Y, Zhang S, Zeng D, et al. Low temperature-induced DNA hypermethylation attenuates expression of RhAG, an AGAMOUS homolog, and increases petal number in rose (Rosa hybrida). BMC Plant Biol 2015;15:237.

[29] Deng JH, Deng P, Lin S-L, Ying S-Y. Gene silencing in vitro and in vivo using intronic microRNAs. Methods MolBiol 2015;1218:321-40

[30] Titze-de-Almeida R, David C, Titze-de-Almeida SS. The Race of 10 Synthetic RNAi-Based Drugs to the Pharmaceutical Market. Pharm Res 2017;34(7):1339-63.

[31] Bilichak A, Kovalchuk I. The Combined Bisulfite Restriction Analysis (COBRA) Assay for the Analysis of Locus-Specific Changes in Methylation Patterns. Methods MolBiol 2017;1456:63-71.

[32] Crater AK, Roscoe S, Roberts M, Ananvoranich S. Antisense technologies in the studying of Toxoplasma gondii. J Microbiol Methods 2017;138:93-9.

[33] Kenan-Eichler M, Leshkowitz D, Tal L, Noor E, Melamed-Bessudo C, Feldman M, et al. Wheat hybridization and polyploidization results in deregulation of small RNAs. Genetics 2011;188(2):263-72.

[34] Schilling E, Rehli M. Global, comparative analysis of tissue-specific promoter CpG methylation. Genomics 2007;90(3):314-23.

[35] Shahabipour F, Barati N, Johnston TP, Derosa G, Maffioli P, Sahebkar A. Exosomes: Nanoparticulate tools for RNA interference and drug delivery. J Cell Physiol 2017;232(7):1660-8.

[36] Chen X, Baldermann S, Cao S, Lu Y, Liu C, Hirata H, et al. Developmental patterns of emission of scent compounds and related gene expression in roses of the cultivar Rosa x hybrida cv . "Yves Piaget". Plant PhysiolBiochem PPB / Société Fr PhysiolVégétale 2015;87:109-14.

[37] Ma N, Chen W, Fan T, Tian Y, Zhang S, Zeng D, et al. Low temperature-induced DNA hypermethylation attenuates expression of RhAG, an AGAMOUS homolog, and increases petal number in rose (Rosa hybrida). BMC Plant Biol 2015;15:237.

[38] Low JSW, Tao Q, Ng KM, Goh HK, Shu X-S, Woo WL, et al. A novel isoform of the 8p22 tumor suppressor gene DLC1 suppresses tumor growth and is frequently silenced in multiple common tumors. Oncogene 2011;30(16):1923-35.

[39] Ying J, Srivastava G, Hsieh W-S, Gao Z, Murray P, Liao S-K, et al. The stress-responsive gene GADD45G is a functional tumor suppressor, with its response to environmental stresses frequently disrupted epigenetically in multiple tumors. Clin Cancer Res An Off J Am Assoc Cancer Res 2005;11(18):6442-9. 